\title{
Shallow Groundwater Quality and Its Controlling Factors in the Su-Xi-Chang Region, Eastern China
}

\author{
Jianwei Bu ${ }^{1,2}$, Ziyong Sun ${ }^{1,2, *}$, Rui Ma ${ }^{1,2}$, Yunde Liu ${ }^{2}$, Xulong Gong ${ }^{3}{ }^{\oplus}$, Zhao Pan ${ }^{2}$ and \\ Wenhao Wei ${ }^{4}$ (1) \\ 1 Technology Innovation Center of Geo-Environmental Restoration, Ministry of Natural Resources, No. 388 \\ Lumo Road, Wuhan 430074, China; jwbu@cug.edu.cn (J.B.); rma@cug.edu.cn (R.M.) \\ 2 School of Environmental Studies, China University of Geosciences, No. 68 Jincheng Street, Wuhan 430078, \\ China; lydcn84@126.com (Y.L.); panzhao@cug.edu.cn (Z.P.) \\ 3 Key Laboratory of Earth Fissures Geological Disaster, Ministry of Natural Resources, No. 700 Zhujiang Road, \\ Nanjing 210018, China; xulonggong@126.com \\ 4 Geological Survey, China University of Geosciences, No. 388 Lumo Road, Wuhan 430074, China; \\ weiwenhao048@cug.edu.cn \\ * Correspondence: ziyong.sun@cug.edu.cn; Tel./Fax: +86-27-6527-7109
}

Received: 18 December 2019; Accepted: 11 February 2020; Published: 16 February 2020

\begin{abstract}
Understanding factors influencing groundwater quality is critical to the development of best management practices at the large watershed scale. In this study, the shallow groundwater $(10-20 \mathrm{~m}$ depth) in the Su-Xi-Chang region, eastern China, was investigated as part of a monitoring program from 2007 to 2008 to analyze the regional groundwater quality as well as the hydrogeochemical processes and their controlling factors. Conventional physicochemical water parameters $(\mathrm{pH}$, turbidity, electrical conductivity, dissolved oxygen, total phosphorus), major cations $\left(\mathrm{Na}^{+}, \mathrm{Ca}^{2+}, \mathrm{Mg}^{2+}\right.$ and $\left.\mathrm{NH}_{4}{ }^{+}\right)$and anions $\left(\mathrm{Cl}^{-}, \mathrm{NO}_{3}{ }^{-}\right.$and $\left.\mathrm{SO}_{4}{ }^{2-}\right)$ were measured. Hydrochemical methods and multivariate statistical methods were applied to analyze the hydrogeochemical signatures, origins, the similarities among the variables and to identify the main pollution sources in the groundwater. The results showed that (1) the concentrations of TDS (224.89-1086.70 mg/L) and turbidity (0.1-18.60 NTU) were higher than the class II groundwater quality standards in China and the WHO drinking water standards, (2) there were extremely high concentrations of ammonia $(0.01-32.90 \mathrm{mg} / \mathrm{L})$, with a mean value of $0.72 \mathrm{mg} / \mathrm{L}$ and (3) the nitrate concentrations (average value of $22.07 \mathrm{mg} / \mathrm{L}$ ) exceeded the class III groundwater quality standards. The study also provided evidence that weathering, dissolution of carbonate, halite and silicate and cation exchange were the possible primary hydrogeochemical control mechanisms in the groundwater. The sources of ammonia, total phosphorus, sulfates and nitrates included rock-water interactions and anthropogenic activities. The groundwater administration of pollution sinks and sources, long-term legal frameworks and economic incentives should be improved to optimize watershed scale management in the context of rapid development in China.
\end{abstract}

Keywords: groundwater quality; multivariate statistics; hydrogeochemical processes; anthropogenic impacts; Su-Xi-Chang region

\section{Introduction}

The water crisis is one of the most serious problems in the 21st century which is in fact continuing to get worse due to anthropogenic activities [1-4]. These activities involve the discharge of increasing amounts of contaminants into water bodies and excessive development and utilization of surface water and groundwater resources [3,5-9]. Owing to rapid urbanization, industrialization and intensified land reclamation, surface water has become destabilized, degraded and contaminated worldwide, 
which makes the availability and quality of groundwater, particularly shallow groundwater $(0 \sim 60 \mathrm{~m})$, an environmental concern [10-12].

Shallow groundwater is the major source of potable, domestic and industrial water throughout the world because in the absence of surface water, developing and utilizing groundwater is the compelling option. Moreover, where groundwater is available, obtaining shallow groundwater is more economical and convenient than deep groundwater [13-15]. However, the shallow groundwater has direct recharging and discharging relationships with local precipitation and surface water and is greatly affected by anthropogenic activities due to shallow buried conditions and rapid circulation [16-18]. Therefore, the quality and safety of shallow groundwater have drawn global attention. Investigating the spatial and temporal variation of shallow groundwater quality at a large scale is particularly useful for developing an effective water management system [19-21].

The Su-Xi-Chang region (including the municipalities of Suzhou, Wuxi and Changzhou) is located in the lower reaches of the Yangtze River in the southern Jiangsu Province. Sitting on the Yangtze River estuary and adjacent to Shanghai, the Su-Xi-Chang region is one of the fastest growing, most prosperous and representative regions in China. In this region, surface water and groundwater have frequent and intense interactions. Meanwhile, the resources of surface water and groundwater are abundant. Due to the shallow burial of shallow groundwater, the aquifer is easily polluted by the sewage discharged from factories and pesticide residues from farmland, which may also inversely influence the surface water body (e.g., Yangtze River, Taihu Lake, East Sea and the Yellow Sea) horizontally and deep groundwater vertically. Hence, it is extremely important to carry out research on shallow groundwater in areas where anthropogenic activities are frequent and the economy is developed, such as the $\mathrm{Su}-\mathrm{Xi}$-Chang region. However, few scientific, systematic and long-term groundwater measuring or monitoring programs have been conducted in this region in recent decades. Many studies regarding the occurrence of land subsidence due to excessive groundwater exploration have been performed in local areas [22-25]. Nevertheless, the hydrochemical characteristics, groundwater formation mechanisms and anthropogenic impacts on groundwater quality due to rapid urbanization and industrialization are less commonly reported.

During the past decade, several approaches have been developed to assess the impacts of anthropogenic activities on water quality. There are two main obstacles to overcome. First, adequate long-term measurements of water quality data are even scarcer than data on water fluxes. Second, the transformation of small-scale process descriptions to the watershed or catchment scale remains an unsolved problem [26]. Multivariate statistical methods can be used to characterize and evaluate the temporal and spatial variations of groundwater quality from complicated datasets [11,27-30]. Spatially referenced regressions of contaminant transport in watershed attribute models have been used as a hybrid process-based and statistical modeling approach for estimating pollutant sources and contaminant transport in waters [31,32]. Recent studies in large watersheds that have utilized remote sensing data and geographical information techniques have been oriented toward quantifying the combined influence of watershed characteristics, land-use changes and social and economic factors on nutrient discharge into rivers [21,30,33-36].

The objectives of the present study were to (1) detect the conventional physicochemical parameters $(\mathrm{pH}$, turbidity, electric conductivity, dissolved oxygen, total phosphorus) of the groundwater, (2) determine the concentrations of major cations $\left(\mathrm{Na}^{+}, \mathrm{Ca}^{2+}, \mathrm{Mg}^{2+}\right.$ and $\left.\mathrm{NH}_{4}{ }^{+}\right)$and anions $\left(\mathrm{Cl}^{-}\right.$, $\mathrm{NO}_{3}$ - and $\mathrm{SO}_{4}{ }^{2-}$ ) in the groundwater, (3) analyze the hydrogeochemical signatures, processes, origins and mechanisms in the study area and (4) identify the anthropogenic impacts on groundwater quality variations in the Su-Xi-Chang region in eastern China. 


\section{Outline of Study Area and Methodology}

\subsection{Study Area}

The Su-Xi-Chang region is situated in the Taihu Lake plain in the Southern Yangtze Delta in the eastern part of China and constitutes approximately $14,649 \mathrm{~km}^{2}$ of the territory; additionally, the average elevation is below $50 \mathrm{~m}$ (decreases from the west to the east), as illustrated in Figure 1. It borders the Mogan Mountain and Maodong Plain in the west, the East Sea and the Yellow Sea in the east, the Yangtze River in the north and Zhejiang Province in the south [23]. The northern subtropical monsoon climate dominates this region year-round, with an average annual temperature of $17.5^{\circ} \mathrm{C}$ and a mean annual precipitation of $1055 \mathrm{~mm}$, all of which are beneficial for hydrological cycling and hydrogeochemical transformation [37].

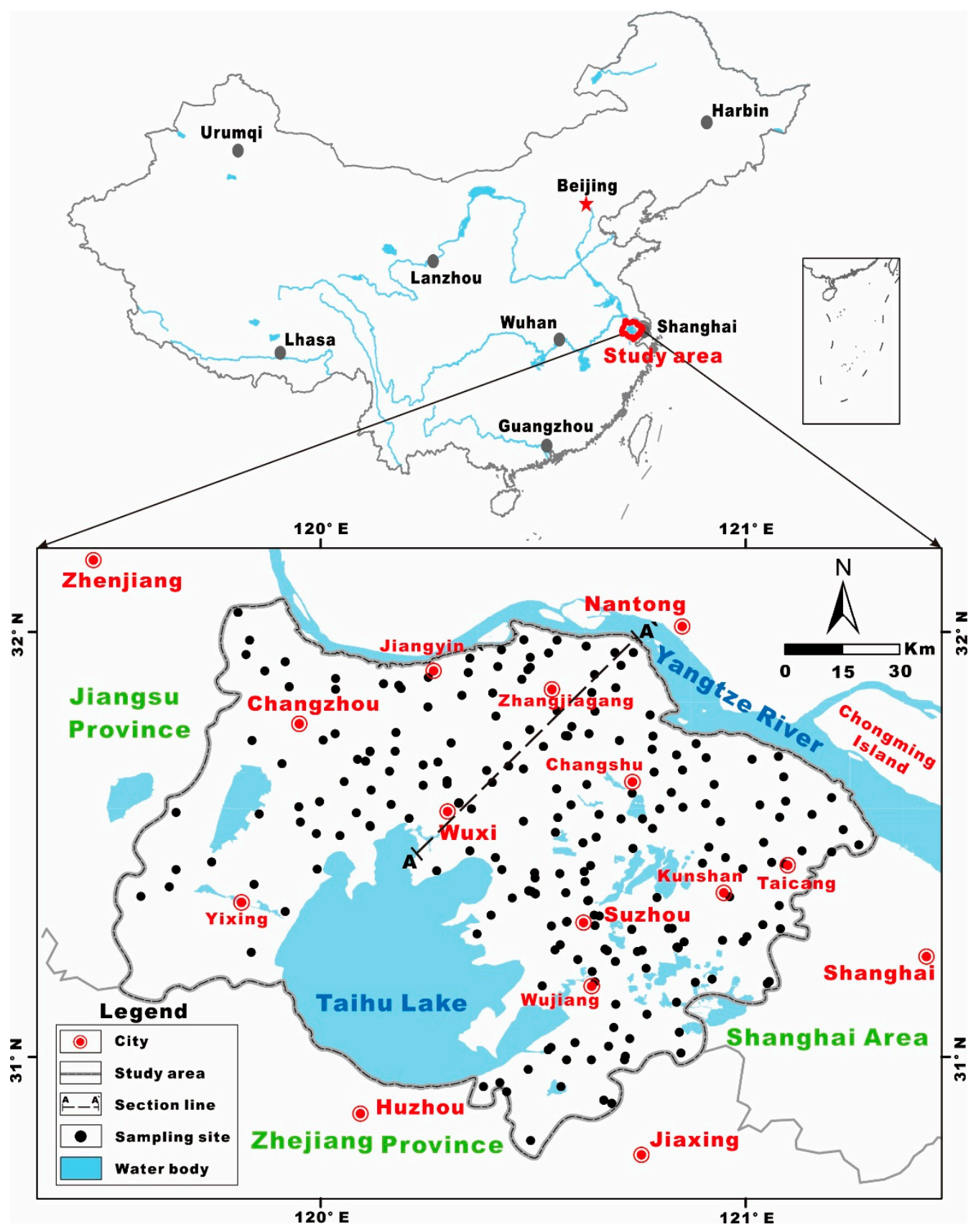

Figure 1. The geographic location of the Su-Xi-Chang region with the sampling sites. 


\subsection{Hydrogeological Conditions}

Various groundwater types, complex buried conditions and uneven spatial distributions of groundwater were observed in the study area, which clearly indicates the regional characteristics [22,24,38]. Pore water in unconsolidated materials is the primary type of groundwater in the plain area. According to the origins, ages, buried distributions, hydraulic connections and hydrochemical characteristics of the aquifers, they were divided into phreatic aquifers and the confined aquifers in the area were labeled from top to bottom as I, II and III $[23,25]$. The soil intervals between the aquifers are viscous and the lithology is dominated by loam and sandy loam with medium-fine sand, which were regarded as lenses for aquitard or aquifuge (Figure 2).

The pore-phreatic aquifer, which is the target aquifer in this study, consisting of Holocene and Upper Pleistocene, loam, sandy loam and silty sand, is distributed throughout the study area. Although the phreatic groundwater quality is complicated, freshwater mostly occupies the area. From the west to the east, the hydrochemical types of phreatic groundwater vary from the $\mathrm{HCO}_{3}-\mathrm{Ca} \cdot \mathrm{Mg}$ type to the $\mathrm{Cl} \cdot \mathrm{HCO}_{3}-\mathrm{Na}$ type.

Confined aquifer I, which is composed of Upper Pleistocene loam, sandy loam, silty sand and medium-fine sand, is characterized by a multi-layered structure with mostly $\mathrm{HCO}_{3}-\mathrm{Na}$-Ca-type groundwater.

As the main groundwater exploitation layer in the study area, confined aquifer II is composed of 1-3 layers of Middle Pleistocene loam, sandy loam, fine sand, medium coarse sand, pebbly coarse sand and gravel. Due to the stability (mostly $\mathrm{HCO}_{3}-\mathrm{Na}$. Ca type) and excellence (mineralization $0.60-0.90 \mathrm{~g} / \mathrm{L}$ ) of the groundwater quality, confined aquifer II is suitable as a direct drinking water source.

Confined aquifer III consists of clay, sandy loam, sand and gravel. The quality of the groundwater in this aquifer is considered to be good and is accompanied by $\mathrm{HCO}_{3}-\mathrm{Ca} \cdot \mathrm{Na}$ and $\mathrm{HCO}_{3} \cdot \mathrm{Cl}-\mathrm{Na} \cdot \mathrm{Ca}$ hydrochemical types and a mineralization of $0.75-0.90 \mathrm{~g} / \mathrm{L}$.

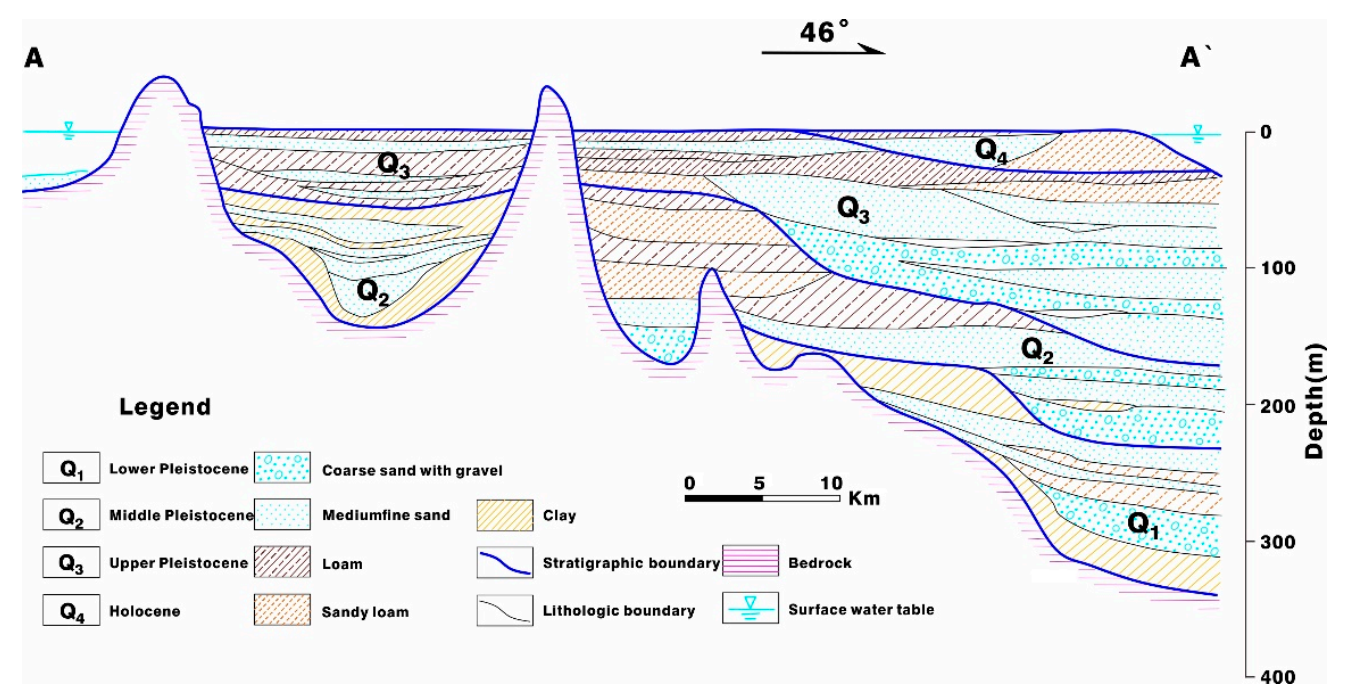

Figure 2. Hydrogeological profile of the Quaternary phreatic and confined aquifers.

\subsection{Sampling and Analytical Methods}

A total of 231 shallow groundwater samples (10 20 $\mathrm{m}$ in depth) were collected throughout the study area as part of a groundwater monitoring program based on existing wells, springs, newly built monitoring wells and boreholes from December 2007 to January 2008. The layout of the high-density sampling sites generally ensured uniformity and representativeness. The elevation and coordinates of the sampling sites were measured and identified using a portable handheld global positioning system (GPS).

Physicochemical parameters were measured at each sampling site and all samples were analyzed for major cations, anions and alkalinity. Water temperature, $\mathrm{pH}$, turbidity, dissolved oxygen (DO) 
and electric conductivity (EC) were measured in the field at the time of collection using a digital handheld multiparameter sampling instrument (YSI ProDSS) [3]. The samples were pretreated during field collection using a degassing filtration system (GM-0.33A, JINTENG) powered by vehicular electricity supply, accompanied with a $0.45 \mu \mathrm{m}$ water-soluble filter membrane and acidified to $\mathrm{pH} \leq 2$ using ultra-pure $\mathrm{HNO}_{3}$ for the cation analysis [39,40]. Without the determination of NOM (Natural Organic Matter) or TOC (Total Organic Carbon), such on-site pretreatment can effectively filter the particle impurities, suspended solids and complexes, and stabilize the cations in the water sample, avoiding subsequent disturbance so as to make the measured results of cations and anions more accurate and the instruments more reliable. After sample collection, each sample was stored in polyethylene bottles that were sealed with parafilm sealing film before further chemical analysis at the State Key Laboratory of Biogeology and Environmental Geology, China University of Geosciences (Wuhan, China).

Major cations $\left(\mathrm{Na}^{+}, \mathrm{Mg}^{2+}\right.$ and $\left.\mathrm{Ca}^{2+}\right)$ were determined by inductively coupled plasma optical emission spectrometry (ICP-OES) (iCAP 6300, Thermo Fisher Scientific) on the filtered and acidified samples. The average analytical error of the major and trace chemical constituents using ICP-OES is less than $\pm 5 \%$. The major anions $\left(\mathrm{Cl}^{-}, \mathrm{NO}_{3}\right.$ - and $\left.\mathrm{SO}_{4}{ }^{2-}\right)$ were detected by ion chromatography (IC) (ICS 1100, DIONEX) with a detection limit of $0.01 \mathrm{mg} / \mathrm{L}$. Alkalinity was measured by in situ titration with $\mathrm{HCl}(0.1 \mathrm{~N})$, using methyl orange as an indicator within $6 \mathrm{~h}$ of sampling. Total phosphorus (TP) was determined by the colorimetric method after previous digestion [3] and the absorbance readings together with the ammonia were performed in a spectrophotometer (1600 PC, Shimadzu).

The ionic balance error was within $\pm 5 \%$, as the percentage relative total of the cation-anion difference was calculated on the sums from each groundwater sample. All analyses yielded analytical errors $<5 \%$ and external precision of known-unknown analytical standards. All procedures of sampling, preservation and transportation to the laboratory were conducted according to standard methods [41].

\subsection{Data Treatment and Analytical Methods}

Multivariate statistical methods, including factor analysis (FA), cluster analysis (CA) and principal component analysis (PCA) were used to analyze the variation in water quality and its relationship with anthropogenic descriptors [21]. PCA is a widely used technique to reduce the dimensions of multivariate data and explain the correlations among large numbers of observed variables by extracting a smaller number of latent factors (i.e., principal components or PCs) [35,42-44]. Eigenvalues represent the amount of variance explained by the data matrix. Loadings represent the relative importance of a given variable in a given component. A positive or negative loading means that the variable is positively or negatively correlated to the component [21]. To improve the interpretability of the results, a PCA with varimax normalized rotation was applied; this can maximize the variances in the loading factor across the variables of each factor [45]. In this study, three principal factors extracted from the variables were retained with eigenvalues greater than 1.0, as determined by the Kaiser criterion [46]. Descriptive statistics, correlation coefficients and PCA were all performed using SPSS Version 19.0.

\section{Results and Discussion}

\subsection{Physicochemical Parameters, Hydrochemical Characteristics and Groundwater Quality}

A statistical summary of the physicochemical parameters of the shallow groundwater in the $\mathrm{Su}-\mathrm{Xi}$-Chang region is given in Table 1 . To assess the suitability of the shallow groundwater over the study area for domestic purposes, the groundwater samples were compared with quality standards for groundwater (GB/T 14848-93 [47]), standards for drinking water quality (GB 5749-2006 [48]) and drinking water quality guidelines [49]. For effective disinfection with chlorine, the $\mathrm{pH}$ should preferably be less than 8 ; however, lower-pH water (approximately $\mathrm{pH} 7$ or less) is more likely to be corrosive [49]. In this study, the $\mathrm{pH}$ in the shallow groundwater was observed within the range from 5.59 to 7.82 with a mean value of 7.0, which indicated that the groundwater was faintly acidic to mildly alkaline and well 
within the permissible limit of 6.5-8.5 [48,49]. Total dissolved solids (TDS) is an important indicator of drinking water quality. According to the World Health Organization (WHO) and the Ministry of Health (MH) of China, the palatability of water with a TDS level of less than approximately $600 \mathrm{mg} / \mathrm{L}$ is generally considered to be good; drinking water becomes significantly and increasingly unpalatable as the TDS levels reach greater than approximately $1000 \mathrm{mg} / \mathrm{L}[48,49]$. In the present study, the TDS levels of the groundwater ranged from 224.89 to $1086.70 \mathrm{mg} / \mathrm{L}$, with an average value of $616.69 \mathrm{mg} / \mathrm{L}$. However, the average TDS level was still higher than the quality standard limits for class II $(\leq 500 \mathrm{mg} / \mathrm{L})$ groundwater established by the State Bureau of Technical Supervision (GB/T 14848-93 [47]). Within this class II limit, the groundwater is recommended to be used for a variety of purposes. Approximately $74 \%$ of the samples in the study area were at TDS levels greater than $500 \mathrm{mg} / \mathrm{L}$.

Table 1. Statistical summary of the physicochemical parameters of shallow groundwater in the Su-Xi-Chang region.

\begin{tabular}{cccccccc}
\hline Parameter & Min. & Max. & Mean & QSGW $^{\mathbf{a}}$ & EQSSW $^{\mathbf{b}}$ & SDWQ $^{\mathbf{c}}$ & GDWQ $^{\mathbf{d}}$ \\
\hline Temperature $\left({ }^{\circ} \mathrm{C}\right)$ & 11.00 & 22.50 & 16.89 & n.s. & n.s. & n.s. & n.s. \\
EC $\left(\mu \mathrm{cm}^{-1}\right)$ & 120.00 & 2850.00 & 1031.26 & n.s. & n.s. & n.s. & n.s. \\
$\mathrm{pH}$ & 5.59 & 7.82 & 7.00 & $6.5-8.5$ & $6-9$ & $6.5-8.5$ & $6.5-8.5$ \\
TDS $\left(\mathrm{mg} \mathrm{L}^{-1}\right)$ & 224.89 & 1086.70 & 616.69 & $\leq 500$ & n.s. & $\leq 1000$ & $\leq 1000$ \\
Turbidity $\left(\mathrm{NTU}^{-1}\right)$ & 0.1 & 18.60 & 3.85 & $\leq 3$ & n.s. & $\leq 1$ & $\leq 1$ \\
DO $\left(\mathrm{mg} \mathrm{O}_{2} \mathrm{~L}^{-1}\right)$ & 0.03 & 5.51 & 0.97 & n.s. & $\geq 6$ & n.s. & n.s. \\
Ammonia $\left(\mathrm{mg} \mathrm{N} \mathrm{L}^{-1}\right)$ & 0.01 & 32.90 & 0.72 & $\leq 0.02$ & $\leq 0.5$ & $\leq 0.5$ & n.s. \\
TP $\left(\mathrm{mg} \mathrm{P} \mathrm{L}^{-1}\right)$ & 0.01 & 2.02 & 0.15 & n.s. & $\leq 0.1$ & n.s. & n.s. \\
\hline
\end{tabular}

n.s. not specified; ${ }^{a}$ Quality standard for groundwater, class II (GB/T 14848-93 [47]); ${ }^{\text {b }}$ Environmental quality standards for surface water, class II (GB 3838-2002 [50]); ' Standards for drinking water quality (GB 5749-2006 [48]); d Guidelines for drinking-water quality [49].

Both turbidity and dissolved oxygen (DO) are important parameters that reflect the quality of groundwater. The turbidity was measured in the range from 0.1 to $18.60 \mathrm{NTU}$, with a mean value of 3.85 in all samples. According to the quality standards for class II groundwater, the turbidity should be less than 3 NTU (GB/T 14848-93 [47]), although this limit is even stricter for drinking water usage [48,49]. Only $30 \%$ of the groundwater samples qualified for drinking condition in terms of turbidity ( $\leq 1$ NTU), while $40 \%$ of the samples failed to reach the class II groundwater conditions. Despite the fact that $\mathrm{DO}$ is not specified in either groundwater standards or drinking water standards, it is critical to the survival of aquatic organisms. The mean DO value was only $0.97 \mathrm{mg} / \mathrm{L}$, which was considered low in the study area.

In water bodies, ammonia and total phosphorus (TP) are important parameters indicative of inorganic pollution that mainly result from anthropogenic impacts. They were used as the primary restrictive descriptors of water pollution control goals in the 12th Five-Year Plan of China (2011-2015) [21]. The reference ammonia concentration value established by the China State Bureau of Technical Supervision (CSBTS) for class II groundwater is $0.02 \mathrm{mg} / \mathrm{L}$. However, the average ammonia value reached $0.72 \mathrm{mg} / \mathrm{L}$ in this study and the maximum value was $32.90 \mathrm{mg} / \mathrm{L}$. Some sampling sites are located in urban areas and are presumably influenced by industrial effluent or domestic sewage discharge, which may contribute to the increased ammonia levels at these points. Although TP is not specified in groundwater or drinking water standards, the maximum and mean values are 2.02 and $0.15 \mathrm{mg} / \mathrm{L}$, respectively, which are high compared with the environmental quality standards for surface water (GB 3838-2002 [50]). The increase in ammonia and phosphorus levels at most sampling sites in strictly rural areas may be attributed to excreta from poultry and livestock and agricultural fertilizers used in the cultivation of farm crops, e.g., soybeans and corn, which are common in the study area.

As shown in Table 2, the major cations and anions in the groundwater show significant spatial variation in the study area. The concentrations of $\mathrm{Ca}^{2+}, \mathrm{Mg}^{2+}$ and $\mathrm{Na}^{+}$in the groundwater over the study area were in the ranges of $26.20-162.00,6.07-64.00$ and $8.32-159.00 \mathrm{mg} / \mathrm{L}$, respectively. The concentrations of $\mathrm{HCO}_{3}{ }^{-}, \mathrm{Cl}^{-}$and $\mathrm{SO}_{4}{ }^{2-}$ in the groundwater were observed in the ranges of 
$113.00-706.00,7.96-191.00$ and $2.45-187.00 \mathrm{mg} / \mathrm{L}$, respectively. More than $98 \%$ of all samples in the study area were within the permissible limits of major cations and anions for drinking water due to the TDS values $\leq 1000 \mathrm{mg} / \mathrm{L}$ (Table 1), excluding only 4 samples with their average TDS value of $1040.30 \mathrm{mg} / \mathrm{L}$. According to the mean values, the major cations and anions in the groundwater in the study area were found in the order of $\mathrm{Ca}^{2+}>\mathrm{Na}^{+}>\mathrm{Mg}^{2+}$ and $\mathrm{HCO}_{3}{ }^{-}>\mathrm{SO}_{4}{ }^{2-}>\mathrm{Cl}^{-}$, respectively.

Table 2. Statistical summary of the hydrogeochemical parameters of the shallow groundwater in the Su-Xi-Chang region.

\begin{tabular}{ccccccc}
\hline Parameter & Min. & Max. & Mean & SD & Skewness & Kurtosis \\
\hline $\mathrm{Ca}^{2+}$ & 26.20 & 162.00 & 90.09 & 28.93 & 0.26 & -0.50 \\
$\mathrm{Mg}^{2+}$ & 6.07 & 64.00 & 30.23 & 11.86 & 0.58 & -0.07 \\
$\mathrm{Na}^{+}$ & 8.32 & 159.00 & 72.63 & 29.23 & 0.63 & 0.05 \\
$\mathrm{Cl}^{-}$ & 7.96 & 191.00 & 84.39 & 36.18 & 0.79 & 0.28 \\
$\mathrm{SO}_{4}{ }^{2-}$ & 2.45 & 187.00 & 89.40 & 39.04 & 0.34 & -0.17 \\
$\mathrm{HCO}_{3}{ }^{-}$ & 113.00 & 706.00 & 353.70 & 132.67 & 0.64 & -0.25 \\
$\mathrm{NO}_{3}{ }^{-}$ & 0.01 & 154.00 & 22.07 & 26.85 & 2.04 & 4.73 \\
$\mathrm{H}_{2} \mathrm{SiO}_{3}$ & 11.10 & 55.40 & 25.14 & 6.87 & 1.31 & 3.01 \\
\hline
\end{tabular}

Units for all chemical indices are $\mathrm{mg} / \mathrm{L}$ except $\mathrm{pH}, \mathrm{SD}$ (standard derivation).

Groundwater nitrate contamination is currently very common and has become a growing problem in many regions of the world. Many researchers have reported serious groundwater nitrate pollution in China [51-55]. In the shallow groundwater in the Su-Xi-Chang region, $\mathrm{NO}_{3}{ }^{-}$showed a wide concentration variation from 0.01 to $154.00 \mathrm{mg} / \mathrm{L}$, with an average of $22.07 \mathrm{mg} / \mathrm{L}$. Approximately $14 \%$ of the shallow groundwater samples have $\mathrm{NO}_{3}{ }^{-}$concentrations greater than $50 \mathrm{mg} / \mathrm{L}$, which is the WHO recommended maximum acceptable guideline value for drinking water [49]. These high concentrations can be attributed to the leaching of $\mathrm{NO}_{3}{ }^{-}$from frequent anthropogenic activities such as fertilization and irrigation of agricultural land and wastewater leakage.

\subsection{Hydrochemical Origin and Correlation Analysis}

Gibbs diagrams have been proposed to investigate the mechanisms controlling the surface water chemistry throughout the world. Gibbs diagrams are constructed by plotting the ratios of $\mathrm{Na} /(\mathrm{Na}+\mathrm{Ca})$ and $\mathrm{Cl} /\left(\mathrm{Cl}+\mathrm{HCO}_{3}\right)$ weights versus TDS separately on a logarithmic axis. Based on extensive water chemistry data from numerous rain, river, lake and ocean samples, Gibbs diagrams have been classified into three dominance domains corresponding to precipitation dominance, rock dominance and evaporation dominance. In recent years, Gibbs diagrams have also been used to evaluate groundwater chemistry. Therefore, in this study, the samples were plotted on Gibbs diagrams to investigate the factors governing the chemistry of the shallow groundwater in the Su-Xi-Chang region.

As shown in Figure 3, all samples were distributed in the middle part (mid-range TDS levels) of the boomerang on the Gibbs diagrams, while $\mathrm{Na} /(\mathrm{Na}+\mathrm{Ca})$ values spanned the entire range $(0.1-0.8)$, which reflected the characteristics of fresh groundwater, unlike most surface water [56]. Almost every sample dropped in the shape of boomerang except for only a few dots with higher $\mathrm{Na} / \mathrm{Na}+\mathrm{Ca}$ ) values than 0.7. It can be inferred that carbonate minerals dominate the groundwater chemistry, accompanying the availability and solubility of silicates minerals [57]. Depending on soil and aquifer properties, all samples fell toward the rock dominance domain, suggesting that rock-water interactions are the major source of dissolved ions in the groundwater in this study. 



Figure 3. Gibbs diagrams for the shallow groundwater in the Su-Xi-Chang region.

To further understand the hydrogeochemical processes regulating the groundwater quality, a correlation analysis was performed and a bivariate diagram was constructed [58]. Pearson correlation (r) was used to examine the correlation between all possible variable pairs. Samples showing $r>0.7$ are considered to be strong, whereas $0.7>\mathrm{r}>0.5$ represents moderate correlation at a significance level $(p)$ of $<0.05$ (Table 3) $[59,60]$.

Table 3. Pearson correlation (r) for the hydrogeochemical parameters of the shallow groundwater in the Su-Xi-Chang region.

\begin{tabular}{cccccccccccc}
\hline Parameter & $\mathrm{pH}$ & $\mathrm{TDS}$ & $\mathrm{Ca}^{2+}$ & $\mathbf{M g}^{2+}$ & $\mathrm{Na}^{+}$ & $\mathrm{Cl}^{-}$ & $\mathrm{SO}_{4}{ }^{2-}$ & $\mathbf{H C O}_{3}^{-}$ & $\mathbf{N O}_{3}^{-}$ & $\mathrm{SiO}_{2}$ \\
\hline $\mathrm{pH}$ & 1 & $0.136^{*}$ & 0.021 & 0.129 & $0.170^{* *}$ & $0.211^{* *}$ & 0.108 & 0.048 & 0.044 & 0.080 \\
$\mathrm{TDS}$ & $0.136^{*}$ & 1 & $0.745^{* *}$ & $0.651^{* *}$ & $0.705^{* *}$ & $0.695^{* *}$ & $0.538^{* *}$ & $0.701^{* *}$ & $0.311^{* *}$ & $0.163^{*}$ \\
$\mathrm{Ca}^{2+}$ & 0.021 & $0.745^{* *}$ & 1 & $0.424^{* *}$ & $0.262^{* *}$ & $0.395^{* *}$ & $0.421^{* *}$ & $0.666^{* *}$ & $0.247^{* *}$ & 0.064 \\
$\mathrm{Mg}^{2+}$ & 0.129 & $0.651^{* *}$ & $0.424^{* *}$ & 1 & $0.442^{* *}$ & $0.466^{* *}$ & $0.246^{* *}$ & $0.710^{* *}$ & -0.019 & -0.037 \\
$\mathrm{Na}^{+}$ & $0.170^{* *}$ & $0.705^{* *}$ & $0.262^{* *}$ & $0.442^{* *}$ & 1 & $0.706^{* *}$ & $0.329^{* *}$ & $0.526^{* *}$ & 0.010 & 0.112 \\
$\mathrm{Cl}^{-}$ & $0.211^{* *}$ & $0.695^{* *}$ & $0.395^{* *}$ & $0.466^{* *}$ & $0.706^{* *}$ & 1 & $0.345^{* *}$ & $0.311^{* *}$ & 0.109 & 0.109 \\
$\mathrm{SO}_{4}{ }^{2-}$ & 0.108 & $0.538^{* *}$ & $0.421^{* *}$ & $0.246^{* *}$ & $0.329^{* *}$ & $0.345^{* *}$ & 1 & 0.008 & $0.343^{* *}$ & $-0.141^{*}$ \\
$\mathrm{HCO}_{3-}^{*}$ & 0.048 & $0.701^{* *}$ & $0.666^{* *}$ & $0.710^{* *}$ & $0.526^{* *}$ & $0.311^{* *}$ & 0.008 & 1 & -0.093 & 0.121 \\
$\mathrm{NO}_{3}{ }^{-}$ & 0.044 & $0.311^{* *}$ & $0.247^{* *}$ & -0.019 & 0.010 & 0.109 & $0.343^{* *}$ & -0.093 & 1 \\
$\mathrm{H}_{2} \mathrm{SiO}_{3}$ & 0.080 & $0.163^{*}$ & 0.064 & -0.037 & 0.112 & 0.109 & $-0.141^{*}$ & 0.121 & 0.005 \\
\hline
\end{tabular}

**: Correlation is significant at the 0.01 level (two-tailed); *: Correlation is significant at the 0.05 level (two-tailed).

As shown in Table 3, TDS was strongly correlated with $\mathrm{Ca}^{2+}, \mathrm{Na}^{+}$and $\mathrm{HCO}_{3}{ }^{-}(\mathrm{r}>0.7)$ and moderately correlated with $\mathrm{Mg}^{2+}, \mathrm{Cl}^{-}$and $\mathrm{SO}_{4}{ }^{2-}$, which indicates that the groundwater salinities were mainly controlled by these ions due to the dissolution of minerals or concentration by evaporation $[61,62]$.

$\mathrm{HCO}_{3}{ }^{-}$was related to $\mathrm{Ca}^{2+}$ and $\mathrm{Mg}^{2+}$ with high correlation coefficients (Table 3), which suggests the possibility of carbonate weathering and dissolution [63,64]. Generally, weathering and dissolution of carbonates such as calcite and dolomite during irrigation, rainfall infiltration and groundwater movement are the major sources of $\mathrm{Ca}^{2+}, \mathrm{Mg}^{2+}$ and $\mathrm{HCO}_{3}{ }^{-}$as follows:

$$
\begin{gathered}
\mathrm{CaCO}_{3}+\mathrm{H}_{2} \mathrm{O}+\mathrm{CO}_{2} \rightarrow \mathrm{Ca}^{2+}+2 \mathrm{HCO}_{3}^{-} \\
\mathrm{CaMg}\left(\mathrm{CO}_{3}\right)_{2}+2 \mathrm{H}_{2} \mathrm{O}+2 \mathrm{CO}_{2} \rightarrow \mathrm{Ca}^{2+}+\mathrm{Mg}^{2+}+4 \mathrm{HCO}_{3}^{-}
\end{gathered}
$$




$$
\begin{gathered}
\mathrm{CaCO}_{3}+\mathrm{H}^{+} \rightarrow \mathrm{Ca}^{2+}+\mathrm{HCO}_{3}^{-} \\
\mathrm{CaMg}\left(\mathrm{CO}_{3}\right)_{2}+2 \mathrm{H}^{+} \rightarrow \mathrm{Ca}^{2+}+\mathrm{Mg}^{2+}+2 \mathrm{HCO}_{3}{ }^{-}
\end{gathered}
$$

Accordingly, the equivalent $\left(\mathrm{Ca}^{2+}+\mathrm{Mg}^{2+}\right) / \mathrm{HCO}_{3}{ }^{-}$ratio (expressed in meq/L) would be $1: 1$ to 2:1 if $\mathrm{Ca}^{2+}, \mathrm{Mg}^{2+}$ and $\mathrm{HCO}_{3}{ }^{-}$in the groundwater originated solely from carbonate weathering [65]. Figure $4 \mathrm{a}$ indicates that carbonate weathering is a dominant hydrogeochemical process that controls the evolution of $\mathrm{Ca}^{2+}, \mathrm{Mg}^{2+}$ and $\mathrm{HCO}_{3}{ }^{-}$in shallow groundwater. Some samples falling below the 1:1 line (Figure 4a) showed a depletion of $\mathrm{Ca}^{2+}+\mathrm{Mg}^{2+}$ relative to $\mathrm{HCO}_{3}{ }^{-}$that suggested other hydrogeochemical processes, such as silicate weathering and/or cation-exchange processes, in the study area. Theoretically, if $\mathrm{Ca}^{2+}$ and $\mathrm{HCO}_{3}{ }^{-}$in the groundwater originated solely from calcite weathering, the equivalent $\mathrm{Ca}^{2+} / \mathrm{HCO}_{3}{ }^{-}$ratio would be 1:1 to 2:1 depending on the relative contribution of carbonic acid and strong acid (sulfuric acid, nitric acid), whereas this ratio is 1:2 to 1:1 for dolomite weathering. Similarly, the equivalent $\mathrm{Mg}^{2+} / \mathrm{HCO}_{3}{ }^{-}$ratio is 1:2 to 1:1 for dolomite weathering depending on the relative contributions of carbonic acid and strong acid, whereas for calcite weathering, this ratio is 0 to 1:2. In the plot of $\mathrm{Ca}^{2+}$ versus $\mathrm{HCO}_{3}{ }^{-}$(Figure $4 \mathrm{~b}$ ), a majority of the samples follow the 1:1 and 1:2 lines, indicating the contribution of both calcite and dolomite weathering to the groundwater chemistry in the study area, which is further supported by Figure 4c.
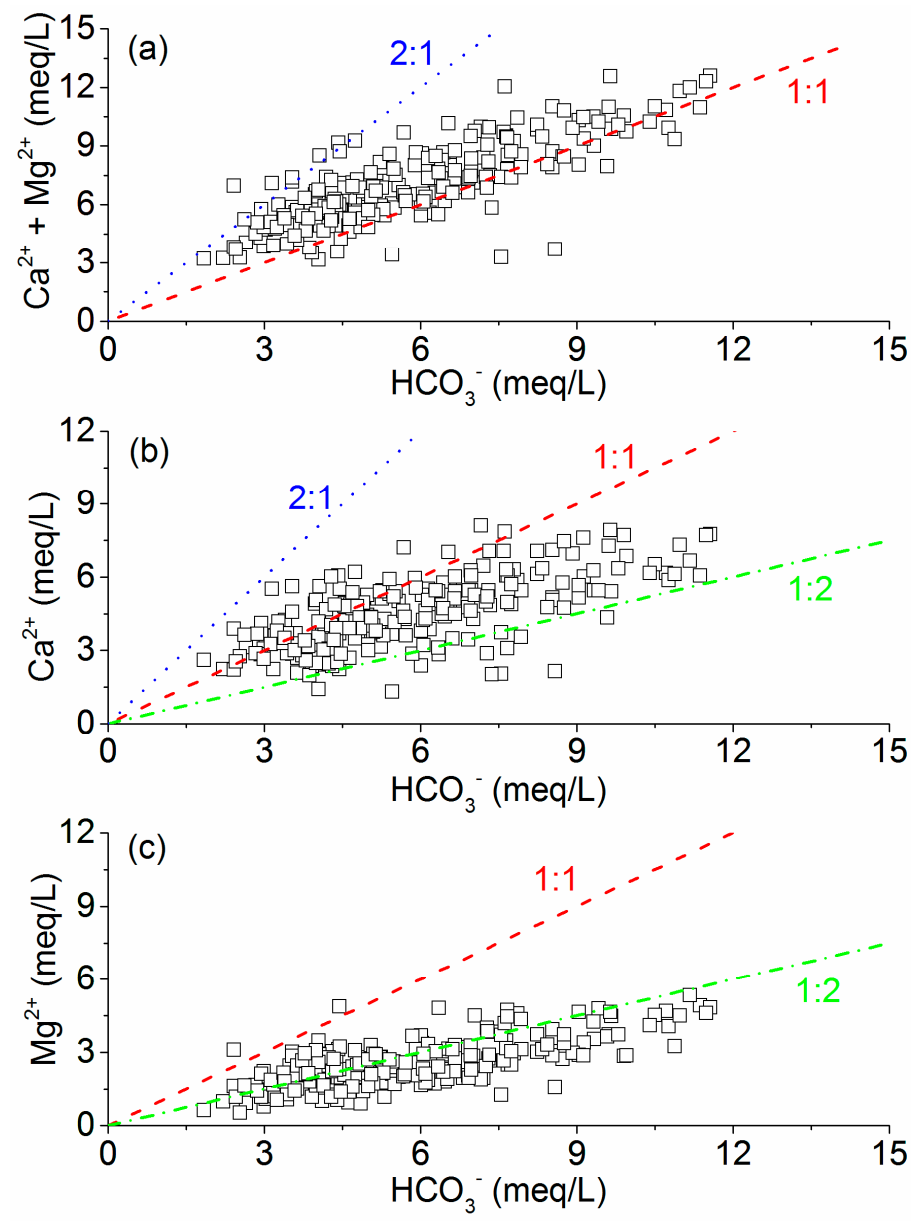

Figure 4. Bivariate diagrams of carbonate weathering and dissolution (a), calcite and dolomite weathering and dissolution $(\mathbf{b}, \mathbf{c})$.

$\mathrm{Na}^{+}$usually comes from halite $(\mathrm{NaCl})$ dissolution and silicate comes from albite weathering. Furthermore, cation exchange may also be responsible for the increase in $\mathrm{Na}^{+}$concentration in groundwater. The influence of the controlled dissolution of halite on the concentrations of $\mathrm{Na}^{+}$and $\mathrm{Cl}^{-}$ 
was suggested by a strongly correlated relationship $(r=0.706)$ between $\mathrm{Na}^{+}$versus $\mathrm{Cl}^{-}$concentrations (Table 3). The dissolution of halite will release equal amounts of $\mathrm{Na}^{+}$and $\mathrm{Cl}^{-}$into the groundwater. In other words, the equivalent $\mathrm{Na}^{+} / \mathrm{Cl}^{-}$ratio would be $1: 1$ if halite dissolution is the sole source of $\mathrm{Na}^{+}$ and $\mathrm{Cl}^{-}$. However, higher $\mathrm{Na}^{+}$concentrations with respect to $\mathrm{Cl}^{-}$than expected from the theoretical 1:1 halite dissolution line were found in most of the groundwater samples (Figure 5a). The equivalent $\mathrm{Na}^{+} / \mathrm{Cl}^{-}$ratio greater than 1 suggests that the groundwater underwent other processes such as silicate weathering (e.g., albite) as well as cation exchange rather than only the halite dissolution process, specifically in those samples with low $\mathrm{Cl}^{-}$concentrations.
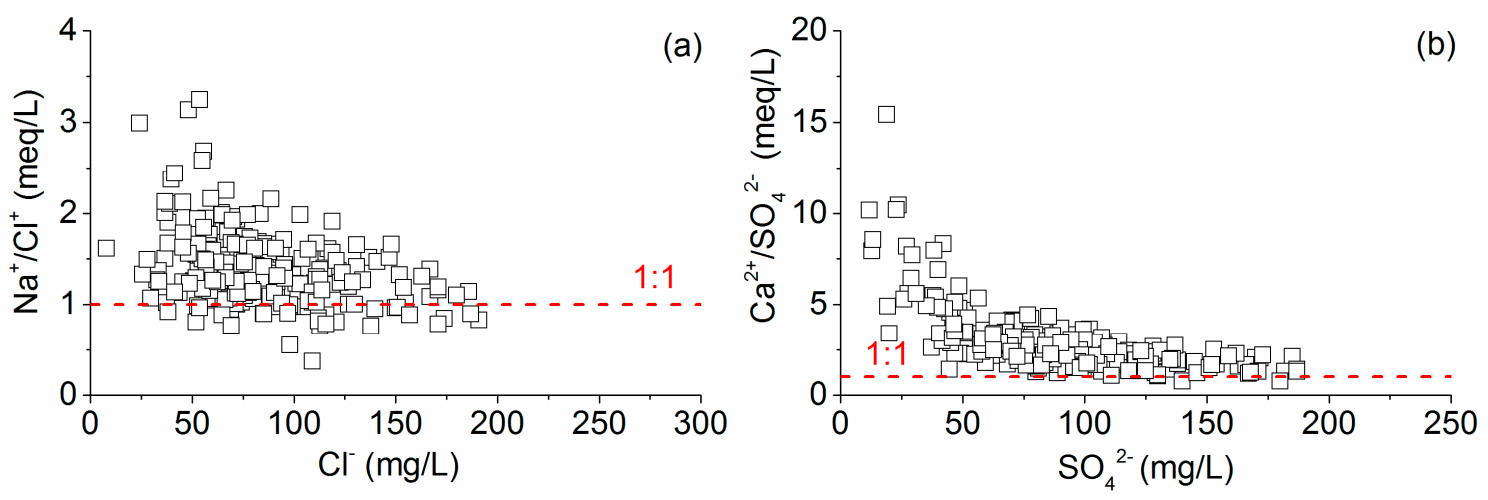

Figure 5. Bivariate diagrams of halite (a) and gypsum/anhydrite (b) weathering and dissolution.

Similarly, the dissolution of gypsum and anhydrite will release equal amounts of $\mathrm{Ca}^{2+}$ and $\mathrm{SO}_{4}{ }^{2-}$ into the groundwater, which means that the equivalent $\mathrm{Ca}^{2+} / \mathrm{SO}_{4}{ }^{2-}$ ratio would be 1:1 if the dissolution of gypsum and anhydrite is the sole source of $\mathrm{Ca}^{2+}$ and $\mathrm{SO}_{4}{ }^{2-}$. In the study area, the dominant source of $\mathrm{Ca}^{2+}$ provided by gypsum and anhydrite dissolution and that of $\mathrm{Na}^{+}$provided by the dissolution of the $\mathrm{Na}_{2} \mathrm{SO}_{4}$ minerals mirabilite and the nardite can be deduced from the highly significant correlations between $\mathrm{Ca}^{2+}$ versus $\mathrm{SO}_{4}{ }^{2-}$ and $\mathrm{Na}^{+}$versus $\mathrm{SO}_{4}{ }^{2-}$ (Table 3). The equivalent $\mathrm{Ca}^{2+} / \mathrm{SO}_{4}{ }^{2-}$ ratio of the groundwater samples usually falls on or above the theoretical 1:1 line of gypsum and anhydrite dissolution and progressively reaches the gypsum and anhydrite dissolution line as the $\mathrm{SO}_{4}{ }^{2-}$ concentrations increase (Figure $5 \mathrm{~b}$ ). This result demonstrated that gypsum dissolution might be a contributing factor to $\mathrm{Ca}^{2+}$ and $\mathrm{SO}_{4}{ }^{2-}$ in the groundwater, especially in the groundwater with high $\mathrm{SO}_{4}{ }^{2-}$ concentrations. The excess of $\mathrm{Ca}^{2+}$ over $\mathrm{SO}_{4}{ }^{2-}$ resulted from the dissolution of carbonates such as calcite and dolomite, which will release $\mathrm{Ca}^{2+}$ into the groundwater but will not release $\mathrm{SO}_{4}{ }^{2-}$. In addition, reverse cation exchange may also increase the concentration of $\mathrm{Ca}^{2+}$ in the groundwater, in which $\mathrm{Ca}^{2+}$ adsorbed in the sediments is exchanged with $\mathrm{Na}^{+}$in the solution.

The relationship between $\mathrm{Ca}^{2+}+\mathrm{Mg}^{2+}$ and $\mathrm{HCO}_{3}{ }^{-}+\mathrm{SO}_{4}{ }^{2-}$ indicates the contribution of the dissolution of carbonates (such as calcite and dolomite) and sulfate minerals (such as anhydrite and gypsum) to the groundwater chemistry [66]. If the dissolution of carbonates and sulfate minerals is the dominant hydrogeochemical process in the groundwater, the $\left(\mathrm{Ca}^{2+}+\mathrm{Mg}^{2+}\right)$ to $\left(\mathrm{HCO}_{3}{ }^{-}+\mathrm{SO}_{4}{ }^{2-}\right)$ stoichiometric ratios in meq/L of the samples should fall along the 1:1 line. However, most groundwater samples in this study showed a deficiency of $\left(\mathrm{Ca}^{2+}+\mathrm{Mg}^{2+}\right)$ relative to $\left(\mathrm{HCO}_{3}{ }^{-}+\mathrm{SO}_{4}{ }^{2-}\right)$ (Figure 6a). This result indicates that these ions were also regulated by other processes rather than only the dissolution of carbonates and sulfate minerals. The excess negative charge of $\left(\mathrm{HCO}_{3}{ }^{-}+\mathrm{SO}_{4}{ }^{2-}\right)$ must be balanced by additional $\mathrm{Na}^{+}$derived from the normal cation exchange process in the clay/weathered layer as well as silicate weathering. Although the excess $\left(\mathrm{Ca}^{2+}+\mathrm{Mg}^{2+}\right)$ over $\left(\mathrm{HCO}^{3-}+\mathrm{SO}_{4}{ }^{2-}\right)$ in a few samples indicates reverse cation exchange, the extent is much less. Furthermore, when cation exchange is a significant geochemical process for controlling the composition of groundwater, the relationship between $\left(\mathrm{Ca}^{2+}+\mathrm{Mg}^{2+}-\mathrm{HCO}_{3}{ }^{-}-\mathrm{SO}_{4}{ }^{2-}\right)$ and $\left(\mathrm{Na}^{+}-\mathrm{Cl}^{-}\right)$should be linear with a slope of approximately $-1[67,68]$. All the groundwater samples from the study area define a straight line $\left(R^{2}=0.78\right)$ with a slope of -1.01 (Figure $6 \mathrm{~b}$ ), which indicates that the cations including $\mathrm{Na}^{+}, \mathrm{Ca}^{2+}$ and $\mathrm{Mg}^{2+}$ participate 
in the ion exchange in the study area. It is also noteworthy that most samples in the study area plot within the fourth quadrant (negative ordinate and positive abscissa). This implies that there is abnormal cation exchange between $\mathrm{Ca}^{2+}$ or $\mathrm{Mg}^{2+}$ in the groundwater and $\mathrm{Na}^{+}$and $\mathrm{K}^{+}$in the aquifer material. In other words, a normal cation exchange reaction may be considered the dominant process that would explain an increase in $\mathrm{Na}^{+}$related to a decrease in $\left(\mathrm{Ca}^{2+}+\mathrm{Mg}^{2+}\right)$. Furthermore, some samples also plot within the second quadrant (positive ordinate and negative abscissa), indicating reverse cation exchange.
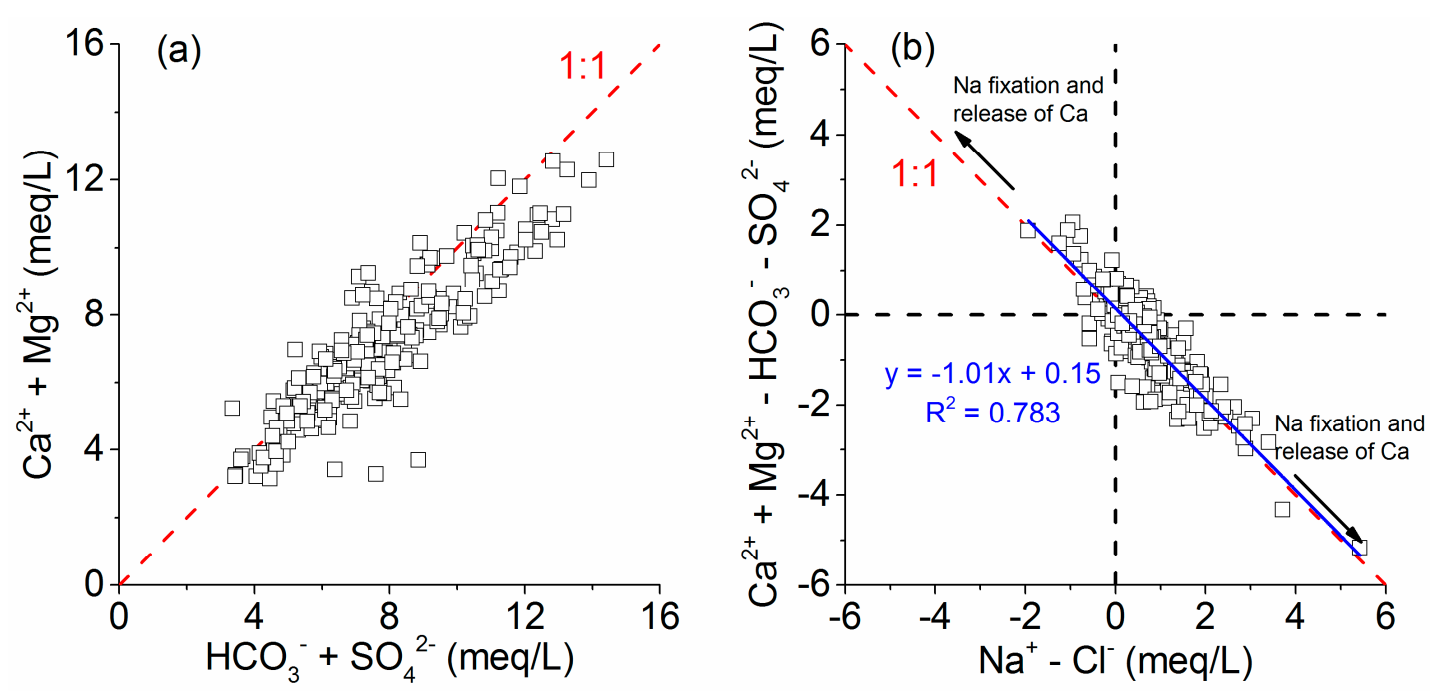

Figure 6. Multivariate diagrams of carbonate and sulfate weathering and dissolution (a), cation exchange (b).

In addition, the weathering of silicate minerals may be another dominant process in the study area, as shown by the dissolved silica data in Table 2. The weathering of albite and/or K-feldspar (Equations (5) and (6)) may also be responsible for the contribution of $\mathrm{Na}^{+}$and/or $\mathrm{K}^{+}$into the groundwater with the equivalent $\mathrm{HCO}_{3}{ }^{-}$.

$$
\begin{gathered}
2 \mathrm{NaAlSi}_{3} \mathrm{O}_{8}+2 \mathrm{CO}_{2}+11 \mathrm{H}_{2} \mathrm{O} \rightarrow 2 \mathrm{Na}^{+}+2 \mathrm{HCO}_{3}{ }^{-}+4 \mathrm{H}_{4} \mathrm{SiO}_{4}+\mathrm{Al}_{2} \mathrm{Si}_{2} \mathrm{O}_{5}(\mathrm{OH})_{4} \\
2 \mathrm{KAlSi}_{3} \mathrm{O}_{8}+2 \mathrm{CO}_{2}+11 \mathrm{H}_{2} \mathrm{O} \rightarrow 2 \mathrm{~K}^{+}+2 \mathrm{HCO}_{3}{ }^{-}+4 \mathrm{H}_{4} \mathrm{SiO}_{4}+\mathrm{Al}_{2} \mathrm{Si}_{2} \mathrm{O}_{5}(\mathrm{OH})_{4}
\end{gathered}
$$

Thus, the samples plotting within the fourth quadrant (negative ordinate and positive abscissa) in the bivariate diagram of $\left(\mathrm{Ca}^{2+}+\mathrm{Mg}^{2+}-\mathrm{HCO}_{3}{ }^{-}-\mathrm{SO}_{4}{ }^{2-}\right)$ and $\left(\mathrm{Na}-\mathrm{Cl}^{-}\right)$may also result from the weathering of soda feldspar (albite) and/or potash feldspars (Figure $6 \mathrm{~b}$ ). The dissolved silica data and the data related to $\mathrm{K}^{+}$and $\mathrm{Na}^{+}$apparently support the explanation that silicate weathering influences the water chemistry in the study area (Tables 2 and 3) [67,68].

\subsection{Principal Component Analysis}

The hydrogeochemical datasets of the 231 groundwater samples were subject to multivariate analysis using principal component analysis (PCA). Table 4 displays the PCA results and the factor loadings of the shallow groundwater in the Su-Xi-Chang region with varimax rotation. Three PCs (FA1, FA2 and FA3) with eigenvalues greater than one [46] were extracted and represented $73.11 \%$ of the total variance in the hydrochemistry. 
Table 4. Rotated component matrix for hydrogeochemical parameters.

\begin{tabular}{ccccc}
\hline \multirow{2}{*}{ Parameter } & \multicolumn{3}{c}{ Factors } & \multirow{2}{*}{ Communality } \\
\cline { 2 - 4 } & FA1 & FA2 & FA3 & 0.956 \\
$\mathrm{nyDS}$ & 0.880 & 0.409 & 0.120 & 0.582 \\
$\mathrm{Ca}^{2+}$ & 0.682 & 0.340 & -0.041 & 0.722 \\
$\mathrm{Mg}^{2+}$ & 0.823 & -0.076 & -0.197 & 0.600 \\
$\mathrm{Na}^{+}$ & 0.740 & 0.130 & 0.190 & 0.584 \\
$\mathrm{Cl}^{-}$ & 0.676 & 0.297 & 0.198 & 0.717 \\
$\mathrm{SO}_{4}^{2-}$ & 0.305 & 0.756 & -0.226 & 0.828 \\
$\mathrm{HCO}_{3}{ }^{-}$ & 0.879 & -0.234 & 0.008 & 0.683 \\
$\mathrm{NO}_{3}{ }^{-}$ & -0.052 & 0.820 & 0.089 & 0.908 \\
$\mathrm{H}_{2} \mathrm{SiO}_{3}$ & 0.083 & -0.057 & 0.948 & - \\
Eigenvalues & 3.796 & 1.697 & 1.087 & - \\
\% of Variance & 42.175 & 18.853 & 12.078 & - \\
\hline
\end{tabular}

Extraction method: Principal component analysis. Rotation method: Varimax with Kaiser normalization.

FA1 was responsible for $42.18 \%$ of the total variance and had highly positive loadings of 0.880 , $0.823,0.740,0.682,0.879$ and 0.676 in TDS, major cations $\left(\mathrm{Mg}^{2+}, \mathrm{Na}^{+}, \mathrm{Ca}^{2+}\right)$ and anions $\left(\mathrm{HCO}_{3}{ }^{-}\right.$, $\left.\mathrm{Cl}^{-}\right)$, respectively. TDS, $\mathrm{Ca}^{2+}, \mathrm{Mg}^{2+}$ and $\mathrm{HCO}_{3}{ }^{-}$are strongly associated, which represents carbonate weathering and ion exchange, as suggested by the correlation analysis. The high affiliation among TDS, $\mathrm{Na}^{+}$and $\mathrm{Cl}^{-}$may be attributed to halite dissolution. This factor is taken as a natural factor of hydrogeochemical processes and origins.

FA2 accounts for $18.85 \%$ of the total variance and is positively correlated with $\mathrm{SO}_{4}{ }^{2-}$ and $\mathrm{NO}_{3}{ }^{-}$, displaying high loadings of 0.756 and 0.820 , respectively. This factor may be attributed to acid rain and human activities (irrigation, fertilizer and manure, domestic sewage, etc.). This result is supported by the fact that significant domestic and agricultural activities, as well as acid deposition due to rapid industrialization, occur in this region [69]. This is a conspicuous factor of anthropogenic impacts that can be confirmed by the aforementioned analysis.

FA3 is dominated by $\mathrm{H}_{2} \mathrm{SiO}_{3}$ with a high loading of 0.948 and accounts for $12.08 \%$ of the total variance. The highly positive correlation between $\mathrm{FA} 3$ and $\mathrm{H}_{2} \mathrm{SiO}_{3}$ can be explained by the process of silicate mineral weathering, which may also be responsible for the cations and anions, as supported by the correlation analysis shown in Table 3. FA3 can be treated as a special factor of hydrogeochemical process and behavior.

The sum of the squared factor loadings for all factors for a given hydrogeochemical parameter (row) is the variance in the variable that is accounted for by all factors and this is called the communality [70]. The communality measures the percent of the variance in a given hydrogeochemical parameter jointly explained by all factors and may be interpreted as the reliability of the indicator. To obtain the variance percentage in a given hydrogeochemical parameter that is accounted for by each factor, the squared factor loadings of the given hydrogeochemical parameter for that factor were divided by the corresponding communality. As shown in Table 5, the variability in TDS may be due to the effects of minerals weathering, dissolution and ion exchange, which can explain $80 \%$ of the three factors. For $\mathrm{Ca}^{2+}, \mathrm{Mg}^{2+}, \mathrm{HCO}_{3}{ }^{-}, \mathrm{Na}^{+}$and $\mathrm{Cl}^{-}$, the contribution from carbonate weathering, halite dissolution and ion exchange can represent $78 \%$ to $94 \%$ of the three factors. The effects of acid rain and/or human activities (FA2) that were attributed to $\mathrm{SO}_{4}{ }^{2-}$ and $\mathrm{NO}_{3}{ }^{-}$were greater than $80 \%$ relative to the other processes included in FA1 and FA3. The processes of silicate mineral weathering, dissolution, reaction, transportation and transformation in the groundwater can be divided from the main major hydrogeochemical processes given that $\mathrm{H}_{2} \mathrm{SiO}_{3}$ in $\mathrm{FA} 3$ dominated $99 \%$ of the three factors. 
Table 5. The percent of variance in a given hydrogeochemical parameter accounted for by each factor.

\begin{tabular}{cccccccccc}
\hline Factors & TDS & $\mathbf{C a}^{2+}$ & $\mathbf{M g}^{2+}$ & $\mathbf{N a}^{+}$ & $\mathbf{C l}^{-}$ & $\mathbf{S O}_{4}{ }^{2-}$ & $\mathbf{H C O}_{3}{ }^{-}$ & $\mathbf{N O}_{3}{ }^{-}$ & $\mathbf{H}_{\mathbf{2}} \mathbf{S i O}_{3}$ \\
\hline FA1 & 0.81 & 0.80 & 0.94 & 0.91 & 0.78 & 0.13 & 0.93 & 0.00 & 0.01 \\
FA2 & 0.18 & 0.20 & 0.01 & 0.03 & 0.15 & 0.80 & 0.07 & 0.98 & 0.00 \\
FA3 & 0.02 & 0.00 & 0.05 & 0.06 & 0.07 & 0.07 & 0.00 & 0.01 & 0.99 \\
\hline
\end{tabular}

\subsection{Anthropogenic Activities and Impacts}

\subsubsection{The Status of Groundwater Exploitation and Utilization}

The exploitation and utilization of porous groundwater in the Su-Xi-Chang region have long histories. As early as the Warring States period more than 2000 years ago, the residents began to excavate the indigenous shaft for daily life usage with a depth of approximately $5 \mathrm{~m}$. According to the survey, there are 4237 deep wells in the study area, with an annual exploitation quantity of $3.37 \times 10^{8} \mathrm{~m}^{3}$, which equals $9.25 \times 10^{5} \mathrm{~m}^{3}$ average daily extraction of groundwater. The exploitation of groundwater has already caused more than $10,000 \mathrm{~km}^{2}$ of regional groundwater drawdown cone and the groundwater in the center of the funnel has been drained (Figure 7).

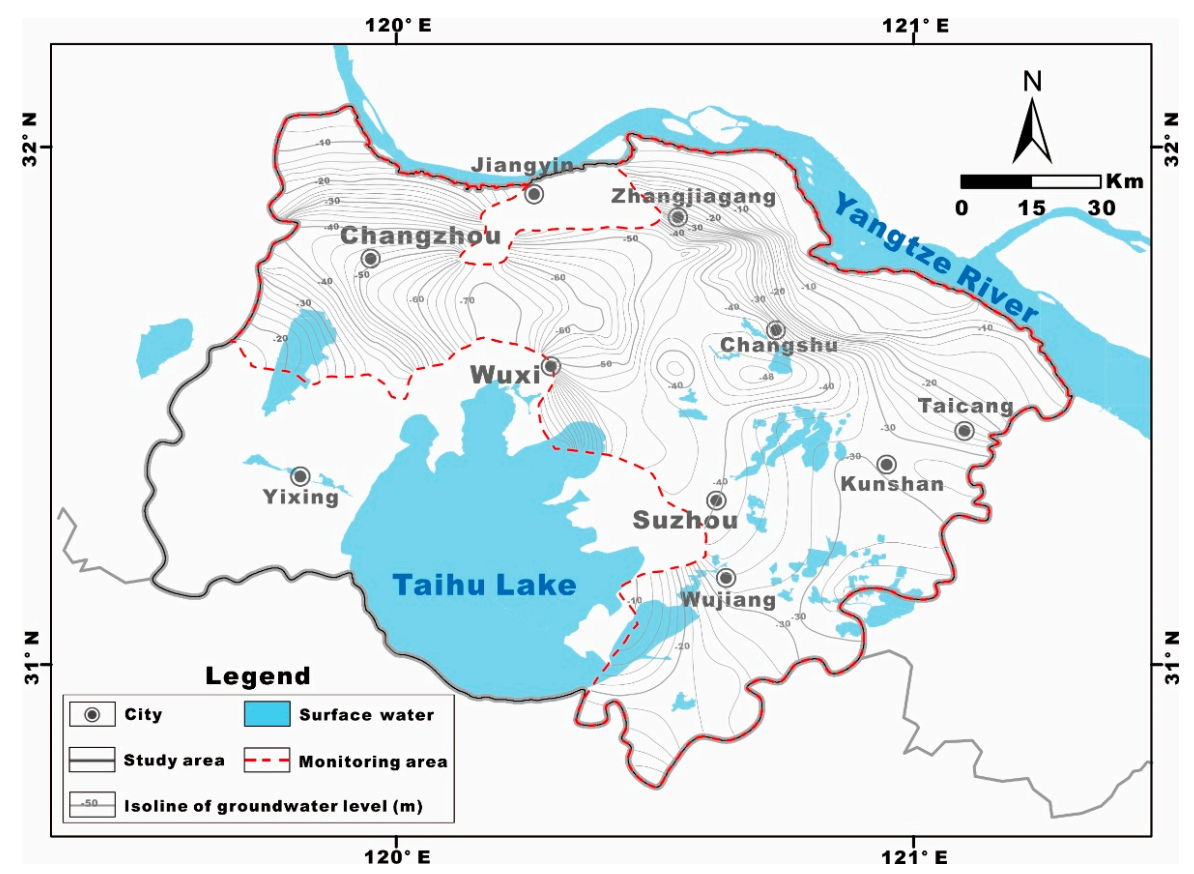

Figure 7. Contour plot of the groundwater table in the Su-Xi-Chang region (2015).

From the view of exploited horizons, confined aquifer II is the main source of groundwater in the study area. In this aquifer, 2978 exploited wells were counted, accounting for $70.29 \%$ of the total number of wells, and the annual exploitation quantity is as high as $2.20 \times 10^{8} \mathrm{~m}^{3}$, accounting for $65.43 \%$ of the total amount of exploitation in the area. Confined aquifer I is the next most utilized source and has 973 wells, accounting for $22.96 \%$ of the total number of wells, and the annual exploitation quantity is $9.41 \times 10^{7} \mathrm{~m}^{3}$, accounting for $27.93 \%$ of the total amount of exploitation. There are 286 wells and the exploitation quantity is $2.24 \times 10^{7} \mathrm{~m}^{3}$ in confined aquifer III, accounting for $6.75 \%$ and $6.64 \%$ of the total number of wells and the annual total exploitation quantity, respectively.

From the perspective of utilization, the exploited deep groundwater is mainly used for industrial production, followed by domestic usage, and these factors account for $59 \%$ and $41 \%$ of the total, respectively. 


\subsubsection{Geological Environmental Problem: Land Subsidence}

Groundwater exploitation often leads to a variety of geological and environmental problems and land subsidence is the main one in the plain region. The occurrence and development of land subsidence in the Su-Xi-Chang region are closely related to groundwater exploitation and these factors are temporally and spatially consistent (Figure 8). Before the 1980s, groundwater exploitation was mainly concentrated in the three cities of Suzhou, Wuxi and Changzhou, and so land subsidence occurred in the central city areas. After the 1990s, large-scale exploitation of groundwater occurred and ground subsidence quickly spread across the entire study area. As the scale and intensity of the exploitation increased, the groundwater table continued to decline and the rate of land subsidence also increased correspondingly.

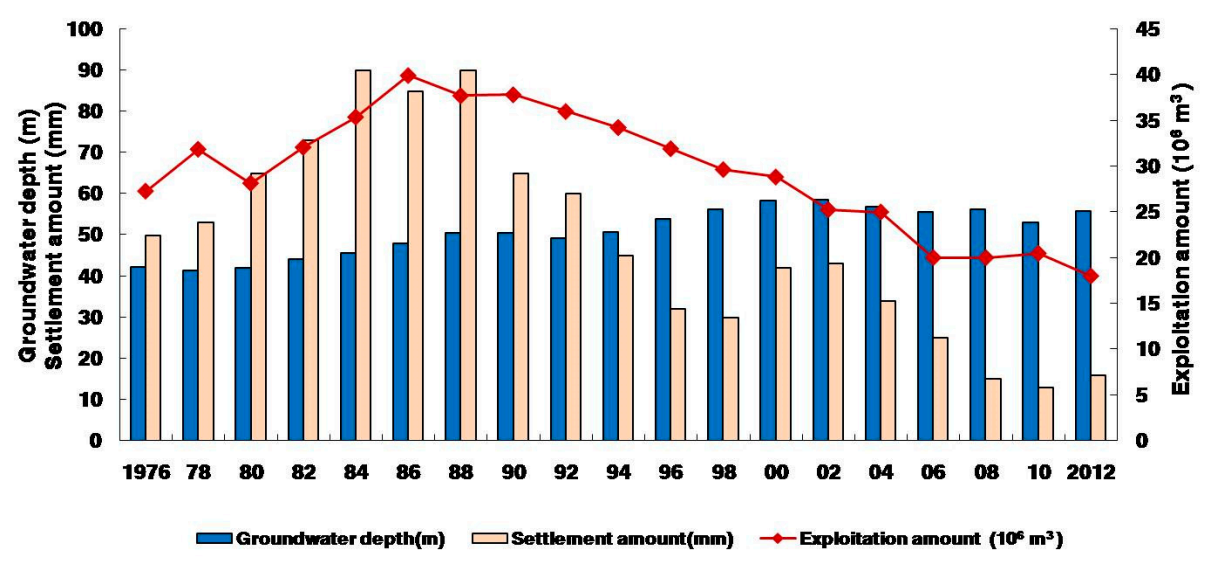

Figure 8. Relationship among groundwater exploitation amount, groundwater depth and settlement amount of land subsidence in the Su-Xi-Chang region.

The area of cumulative settlement that is greater than $200 \mathrm{~mm}$ covers more than $5770 \mathrm{~km}^{2}$, accounting for approximately $40 \%$ of the total $\mathrm{Su}-\mathrm{Xi}$-Chang region. Moreover, the $600 \mathrm{~mm}$ contour has been conjoined in three central cities, occupying an area of more than $1500 \mathrm{~km}^{2}$ (Figure 9).

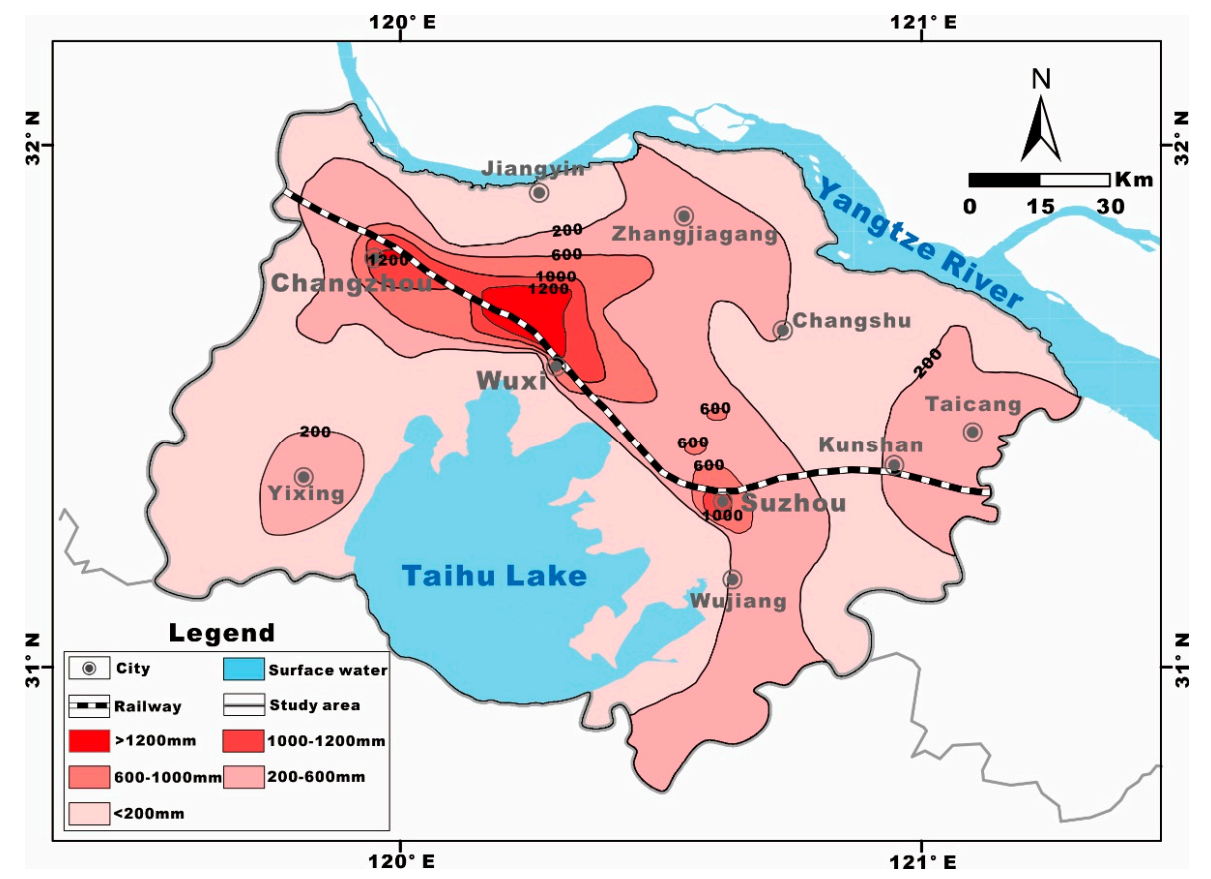

Figure 9. Land subsidence contour plot of cumulative settlement amount in the Su-Xi-Chang region (2015). 


\section{Conclusions}

Higher values of TDS (224.89-1086.70 mg/L), turbidity (0.1-18.60 NTU) and nitrate (0.01-154.00 mg/L) were observed in some samples according to the China groundwater quality standards and WHO drinking water standards. Furthermore, extremely high ammonia concentrations were detected and the concentration of ammonia $(0.01-32.90 \mathrm{mg} / \mathrm{L})$ had a mean value of $0.72 \mathrm{mg} / \mathrm{L}$, which exceeded the class II groundwater quality standards in China by 36 times. Weathering, dissolution of carbonate, halite and silicate, as well as cation exchange, were suggested as the main mechanisms controlling the hydrogeochemical signatures and processes in this region. Anthropogenic activities, such as agricultural practices, waste discharge, acid rain, land use and reclamation, accompanied by rock-water interactions, were mainly responsible for the increased concentrations of ammonia, total phosphorus, sulfates and nitrates. Constant assessment and continuous monitoring of groundwater are urgently needed to safeguard the health of the communities and to ensure sustainable development in the Su-Xi-Chang region.

Author Contributions: Conceptualization, Z.S., R.M. and Y.L.; software, Z.P. and W.W.; validation, Y.L.; formal analysis, J.B., Z.S. and Y.L.; investigation, Y.L., Z.P. and W.W.; resources, Z.S. and X.G.; data curation, J.B.; writing-original draft preparation, J.B.; writing-review and editing, Z.S. and R.M.; visualization, Z.P. and W.W.; supervision, R.M.; project administration, Y.L. and X.G.; funding acquisition, J.B. All authors have read and agreed to the published version of the manuscript.

Funding: National Natural Science Foundations of China: 41722208, 41907177; Natural Science Foundation of Hubei Province: 2019CFA013.

Acknowledgments: This research was supported by the Fundamental Research Funds for the Central Universities (CUGL180817) and the Key Laboratory of Earth Fissures Geological Disaster, Ministry of Natural Resources of the People's Republic of China.

Conflicts of Interest: The authors declare no conflict of interest.

\section{References}

1. Harguinteguy, C.A.; Cofré, M.N.; Fernández-Cirelli, A.; Pignata, M.L. The macrophytes Potamogeton pusillus L. and Myriophyllum aquaticum (Vell.) Verdc. as potential bioindicators of a river contaminated by heavy metals. Microchem. J. 2015, 124, 228-234. [CrossRef]

2. Hillel, N.; Geyer, S.; Licha, T.; Khayat, S.; Laronne, J.B.; Siebert, C. Water quality and discharge of the Lower Jordan River. J. Hydrol. 2015, 527, 1096-1105. [CrossRef]

3. Palácio, S.M.; Pauli, A.R.D.; Piana, P.A.; Queiroz, C.B.; Fabris, S.C.; Fagundes-Klen, M.R.; Veit, M.T. Assessment of anthropogenic impacts on the water quality of Marreco River, Brazil, based on principal component analysis and toxicological assays. Water Air Soil Pollut. 2016, 227, 307. [CrossRef]

4. Hanrahan, M.; Inr, B.D. The rocky path to source water protection: A cross-case analysis of drinking water crises in small communities in Canada. Water 2017, 9, 388. [CrossRef]

5. Kiedrzyńska, E.; Kiedrzyński, M.; Urbaniak, M.; Magnuszewski, A.; Skłodowski, M.; Wyrwicka, A.; Zalewski, M. Point sources of nutrient pollution in the lowland river catchment in the context of the Baltic Sea eutrophication. Ecol. Eng. 2014, 70, 337-348. [CrossRef]

6. Qiang, F.; Tian, X.L.; Dong, L.; He, D. Simulation study of the sustainable utilization of urban water resources based on system dynamics: A case study of Jiamusi. Water Sci. Technol. Water Supply 2016, 16, 980-991. [CrossRef]

7. Li, P.; Tian, R.; Xue, C.; Wu, J. Progress, opportunities, and key fields for groundwater quality research under the impacts of human activities in China with a special focus on western China. Environ. Sci. Pollut. Res. Int. 2017, 24, 13224. [CrossRef] [PubMed]

8. Liao, H.; Sarver, E.; Krometis, L.H. Interactive effects of water quality, physical habitat, and watershed anthropogenic activities on stream ecosystem health. Water Res. 2017, 130, 69. [CrossRef]

9. Hoang, H.; Duong, T.T.; Nguyen, K.T.; Le, Q.; Luu, M.; Trinh, D.A.; Le, A.H.; Ho, C.T.; Dang, K.D.; Némery, J. Impact of anthropogenic activities on water quality and plankton communities in the Day River (Red River Delta, Vietnam). Environ. Monit. Assess. 2018, 190, 67. [CrossRef] 
10. Carpenter, S.R.; Caraco, N.F.; Correll, D.L.; Howarth, R.W.; Sharpley, A.N.; Smith, V.H. Non-point pollution of surface waters eith phosphorus and nitrogen. Ecol. Appl. 1998, 8, 559-568. [CrossRef]

11. Huang, J.; Du, P. Assessment of temporal and spatial variation of coastal water quality and source identification along Macau peninsula. Stoch. Environ. Res. Risk Assess. 2011, 25, 353-361. [CrossRef]

12. Mouri, G.; Takizawa, S.; Oki, T. Spatial and temporal variation in nutrient parameters in stream water in a rural-urban catchment, Shikoku, Japan: Effects of land cover and human impact. J. Environ. Manag. 2011, 92, 1837. [CrossRef] [PubMed]

13. Rahman, A. A GIS based DRASTIC model for assessing groundwater vulnerability in shallow aquifer in Aligarh, India. Appl. Geogr. 2008, 28, 32-53. [CrossRef]

14. Gao, X.; Bai, Y.; Huo, Z.; Xu, X.; Huang, G.; Xia, Y.; Steenhuis, T.S. Deficit irrigation enhances contribution of shallow groundwater to crop water consumption in arid area. Agric. Water Manag. 2017, 185, 116-125. [CrossRef]

15. Leite, N.K.; Stolberg, J.; Cruz, S.P.D.; Tavela, A.D.O.; Safanelli, J.L.; Marchini, H.R.; Exterkoetter, R.; Leite, G.M.C.; Krusche, A.V.; Johnson, M.S. Hydrochemistry of shallow groundwater and springs used for potable supply in Southern Brazil. Environ. Earth Sci. 2018, 77, 80. [CrossRef]

16. Chen, A.; Lei, B.; Hu, W.; Wang, H.; Zhai, L.; Mao, Y.; Fu, B.; Zhang, D. Temporal-spatial variations and influencing factors of nitrogen in the shallow groundwater of the nearshore vegetable field of Erhai Lake, China. Environ. Sci. Pollut. Res. 2018, 25, 4858-4870. [CrossRef]

17. Wang, Z.R.; Tian, X.; Wu, X. Hydrochemical characteristics and quality assessment of shallow groundwater and CBM co-produced water in the Shizhuangnan block, Qinshui Basin, China. Environ. Earth Sci. 2018, 77, 57. [CrossRef]

18. Wu, J.; Sun, Z. Evaluation of shallow groundwater contamination and associated human health risk in an alluvial plain impacted by agricultural and industrial activities, Mid-west China. Expo. Health 2016, 8, 311-329. [CrossRef]

19. Baker, A. Land use and water quality. Hydrol. Process. 2003, 17, 2499-2501. [CrossRef]

20. He, C.; Malcolm, S.B.; Dahlberg, K.A.; Fu, B. A conceptual framework for integrating hydrological and biological indicators into watershed management. Landsc. Urban Plan. 2000, 49, 25-34. [CrossRef]

21. Sun, R.H.; Wang, Z.M.; Chen, L.D. Assessment of surface water quality at large watershed scale: Land-use, anthropogenic, and administrative impacts. J. Am. Water Resour. Assoc. 2013, 49, 741-752. [CrossRef]

22. Shi, X.Q.; Xue, Y.Q.; Ye, S.J.; Wu, J.C.; Zhang, Y.; Yu, J. Characterization of land subsidence induced by groundwater withdrawals in Su-Xi-Chang area, China. Environ. Geol. 2007, 52, 27-40. [CrossRef]

23. Shi, X.; Wu, J.; Ye, S.; Zhang, Y.; Xue, Y.; Wei, Z.; Li, Q.; Yu, J. Regional land subsidence simulation in Su-Xi-Chang area and Shanghai City, China. Eng. Geol. 2008, 100, 27-42. [CrossRef]

24. Wu, J.C.; Shi, X.Q.; Ye, S.J.; Xue, Y.Q.; Zhang, Y.; Yu, J. Numerical simulation of land subsidence induced by groundwater overexploitation in Su-Xi-Chang area, China. Environ. Geol. 2009, 57, 1409-1421. [CrossRef]

25. Yun, Z.; Xue, Y.Q.; Wu, J.C.; Shi, X.Q.; Yu, J. Excessive groundwater withdrawal and resultant land subsidence in the Su-Xi-Chang area, China. Environ. Earth Sci. 2010, 61, 1135-1143.

26. Fohrer, N. Assessment of anthropogenic impacts on water quality. Phys. Chem. Earth 2005, 30, 471. [CrossRef]

27. Simeonov, V.; Stratis, J.A.; Samara, C.; Zachariadis, G.; Voutsa, D.; Anthemidis, A.; Sofoniou, M.; Kouimtzis, T. Assessment of the surface water quality in Northern Greece. Water Res. 2003, 37, 4119. [CrossRef]

28. Singh, K.P.; Malik, A.; Mohan, D.; Sinha, S. Multivariate statistical techniques for the evaluation of spatial and temporal variations in water quality of Gomti River (India)—A case study. Water Res. 2004, 38, 3980. [CrossRef]

29. Vega, M.; Pardo, R.; Barrado, E.; Debán, L. Assessment of seasonal and polluting effects on the quality of river water by exploratory data analysis. Water Res. 1998, 32, 3581-3592. [CrossRef]

30. Tong, S.T.; Chen, W. Modeling the relationship between land use and surface water quality. J. Environ. Manag. 2002, 66, 377. [CrossRef]

31. Preston, S.D.; Alexander, R.B.; Schwarz, G.E.; Crawford, C.G. Factors affecting stream nutrient loads: A synthesis of regional SPARROW model results for the continental United States. J. Am. Water Resour. Assoc. 2011, 47, 891. [CrossRef] [PubMed]

32. Smith, R.A.; Schwarz, G.E.; Alexander, R.B. Regional interpretation of water-quality monitoring data. Water Resour. Res. 1997, 33, 2781-2798. [CrossRef] 
33. Gémesi, Z.; Downing, J.A.; Cruse, R.M.; Anderson, P.F. Effects of watershed configuration and composition on downstream lake water quality. J. Environ. Qual. 2011, 40, 517-527. [CrossRef] [PubMed]

34. Lu, P.; Mei, K.; Zhang, Y.; Liao, L.; Long, B.; Dahlgren, R.A.; Zhang, M. Spatial and temporal variations of nitrogen pollution in Wen-Rui Tang River watershed, Zhejiang, China. Environ. Monit. Assess. 2011, 180, 501-520. [CrossRef]

35. Shrestha, S.; Kazama, F. Assessment of surface water quality using multivariate statistical techniques: A case study of the Fuji river basin, Japan. Environ. Model. Softw. 2007, 22, 464-475. [CrossRef]

36. Wise, D.R.; Johnson, H.M. Surface-water nutrient conditions and sources in the United States Pacific Northwest. J. Am. Water Resour. Assoc. 2011, 47, 1110. [CrossRef]

37. Long, H.; Liu, Y.; Wu, X.; Dong, G. Spatio-temporal dynamic patterns of farmland and rural settlements in $\mathrm{Su}-\mathrm{Xi}-\mathrm{Chang}$ region: Implications for building a new countryside in coastal China. Land Use Policy 2009, 26, 322-333. [CrossRef]

38. Zhang, Y.; Wang, Z.; Xue, Y.; Wu, J.; Yu, J. Mechanisms for earth fissure formation due to groundwater extraction in the Su-Xi-Chang area, China. Bull. Eng. Geol. Environ. 2016, 75, 745-760. [CrossRef]

39. Cuoco, E.; Darrah, T.H.; Buono, G.; Eymold, W.K.; Tedesco, D. Differentiating natural and anthropogenic impacts on water quality in a hydrothermal coastal aquifer (Mondragone Plain, Southern Italy). Environ. Earth Sci. 2015, 73, 7115-7134. [CrossRef]

40. Mapoma, H.W.T.; Xie, X.; Liu, Y.; Zhu, Y.; Kawaye, F.P.; Kayira, T.M. Hydrochemistry and quality of groundwater in alluvial aquifer of Karonga, Malawi. Environ. Earth Sci. 2017, 76, 335. [CrossRef]

41. APHA/AWWA/WEF. Standard Methods for the Examination of Water and Wastewater, 21st ed.; American Public Health Association: Washington, DC, USA, 2005.

42. Bu, J.W.; Sun, Z.Y.; Zhou, A.G.; Xu, Y.N.; Ma, R.; Wei, W.H.; Liu, M. Heavy metals in surface soils in the upper reaches of the Heihe River, northeastern Tibetan Plateau, China. Int. J. Environ. Res. Public Health 2016, 13, 247. [CrossRef]

43. Loska, K.; Wiechuła, D. Application of principal component analysis for the estimation of source of heavy metal contamination in surface sediments from the Rybnik Reservoir. Chemosphere 2003, 51, 723-733. [CrossRef]

44. Ma, H.; Liu, L.; Chen, T. Water security assessment in Haihe River Basin using principal component analysis based on Kendall tau. Environ. Monit. Assess. 2010, 163, 539. [CrossRef]

45. Han, Y.M.; Du, P.X.; Cao, J.J.; Posmentier, E.S. Multivariate analysis of heavy metal contamination in urban dusts of Xi'an, Central China. Sci. Total Environ. 2006, 355, 176-186.

46. Kaiser, H.F. The application of electronic computers to factor analysis. Educ. Psychol. Meas. 1960, $20,141-151$. [CrossRef]

47. CSBTS (China State Bureau of Technical Supervision). Quality standard for ground water (GB/T 14848-93). 1993. Available online: https://www.chinesestandard.net/PDF/English.aspx/GBT14848-1993 (accessed on 17 December 2019).

48. $\mathrm{MH}$ (Ministry of Health of China). Standards for Drinking Water Qual. (GB 5749-2006). 2006. Available online: http:/tradechina.dairyaustralia.com.au/wp-content/uploads/2018/08/GB-5749-2006-Standards-forDrinking-Water-Quality.pdf (accessed on 17 December 2019).

49. WHO (World Health Organization). Guidelines for Drinking-Water Quality, 4rd ed.; World Health Organization: Geneva, Switzerland, 2011.

50. SEPA (State Environmental Protection Administration of China). Environmental Quality Standards for Surface Water (GB 3838-2002). 2002. Available online: https://www.codeofchina.com/standard/GB3838-2002.html (accessed on 17 December 2019).

51. Dong, Z.H.; Ji, L.I.; Sun, L.M. Nitrate contamination in the groundwater of intensive vegetable cultivation areas in Shouguang City, Shandong Province, China. J. Agro-Environ. Sci. 2005, 24, 1139-1144.

52. Jin, Z.; Pan, Z.; Jin, M.; Li, F.; Wan, Y.; Gu, B. Determination of nitrate contamination sources using isotopic and chemical indicators in an agricultural region in China. Agric. Ecosyst. Environ. 2012, 155, 78-86. [CrossRef]

53. Ju, X.T.; Kou, C.L.; Zhang, F.S.; Christie, P. Nitrogen balance and groundwater nitrate contamination: Comparison among three intensive cropping systems on the North China Plain. Environ. Pollut. 2006, 143, 117-125. [CrossRef] 
54. Su, X.S.; Wang, H.; Zhang, Y.L. Health risk assessment of nitrate contamination in groundwater: A case study of an agricultural area in Northeast China. Water Resour. Manag. 2013, 27, 3025-3034. [CrossRef]

55. Yang, R.; Liu, W.J. Nitrate contamination of groundwater in an agroecosystem in Zhangye Oasis, Northwest China. Environ. Earth Sci. 2010, 61, 123-129. [CrossRef]

56. Marandi, A.; Shand, P. Groundwater chemistry and the Gibbs Diagram. Appl. Geochem. 2018, 97, $209-212$. [CrossRef]

57. Banks, D.; Frengstad, B. Evolution of groundwater chemical composition by plagioclase hydrolysis in Norwegian anorthosites. Geochim. Cosmochim. Acta 2006, 70, 1337-1355. [CrossRef]

58. Pablo, H.T.F.; Chacón-Moscoso, S.; Barbero-García, I.; Vila-Abad, E. Polychoric versus Pearson correlations in exploratory and confirmatory factor analysis of ordinal variables. Qual. Quant. 2010, 44, 153-166.

59. Adams, S.; Titus, R.; Pietersen, K.; Tredoux, G.; Harris, C. Hydrochemical characteristics of aquifers near Sutherland in the Western Karoo, South Africa. J. Hydrol. 2001, 241, 91-103. [CrossRef]

60. Ly, A.; Marsman, M.; Wagenmakers, E.J. Analytic posteriors for Pearson's correlation coefficient. Stat. Neerl. 2018, 72, 4-13. [CrossRef]

61. An, Y.; Lu, W. Hydrogeochemical processes identification and groundwater pollution causes analysis in the northern Ordos Cretaceous Basin, China. Environ. Geochem. Health 2017, 40, 1209-1219. [CrossRef]

62. Li, Z.; Wang, G.; Wang, X.; Wan, L.; Shi, Z.; Wanke, H.; Uugulu, S.; Uahengo, C.-I. Groundwater quality and associated hydrogeochemical processes in Northwest Namibia. J. Geochem. Explor. 2018, 186, $202-214$. [CrossRef]

63. Wang, W.; Song, X.; Ma, Y. Characterization of controlling hydrogeochemical processes using factor analysis in Puyang Yellow River irrigation district (China). Hydrol. Res. 2017, 48, 1438-1454. [CrossRef]

64. Keita, S.; Tang, Z. The assessment of processes controlling the spatial distribution of hydrogeochemical groundwater types in Mali using multivariate statistics. J. Afr. Earth Sci. 2017, 134, 573-589. [CrossRef]

65. El Alfy, M.; Lashin, A.; Abdalla, F.; Al-Bassam, A. Assessing the hydrogeochemical processes affecting groundwater pollution in arid areas using an integration of geochemical equilibrium and multivariate statistical techniques. Environ. Poll. 2017, 229, 760-770. [CrossRef]

66. Sánchez, E.R.S.; Hoyos, S.E.G.; Esteller, M.V.; Morales, M.M.; Astudillo, A.O. Hydrogeochemistry and water-rock interactions in the urban area of Puebla Valley aquifer (Mexico). J. Geochem. Explor. 2017, 181, 219-235. [CrossRef]

67. Subramani, T.; Rajmohan, N.; Elango, L. Groundwater geochemistry and identification of hydrogeochemical processes in a hard rock region, Southern India. Environ. Monit. Assess. 2010, 162, 123. [CrossRef]

68. Ahmed, M.A.; Samie, S.G.A.; Badawy, H.A. Factors controlling mechanisms of groundwater salinization and hydrogeochemical processes in the Quaternary aquifer of the Eastern Nile Delta, Egypt. Environ. Earth Sci. 2013, 68, 369-394. [CrossRef]

69. Larssen, T.; Lydersen, E.; Tang, D.; He, Y.; Gao, J.; Liu, H.; Duan, L.; Seip, H.M.; Vogt, R.D.; Mulder, J. Acid rain in China. Environ. Sci. Technol. 2006, 40, 418. [CrossRef] [PubMed]

70. Kenny, D.A. Statistics for the Social and Behavioral Sciences; Little, Brown and Company: Boston, MA, USA, 1986.

(C) 2020 by the authors. Licensee MDPI, Basel, Switzerland. This article is an open access article distributed under the terms and conditions of the Creative Commons Attribution (CC BY) license (http://creativecommons.org/licenses/by/4.0/). 